\title{
Influence of Temperature on Development and Reproduction of Ditylenchus weischeri and D. dipsaci on Yellow Pea
}

\author{
Abolfazl Hajihassani and Mario Tenuta, Department of Soil Science, and Robert H. Gulden, Department of Plant Science, University of
} Manitoba, Winnipeg, MB, R3T 2N2 Canada

\begin{abstract}
The ability of the recently described stem nematode of creeping thistle (Cirsium arvense L.), Ditylenchus weischeri, to develop on and parasitize yellow pea (Pisum sativum L.) is uncertain. The current study examined nematode life-stage progression and generation time on yellow pea as affected by temperature with the related pest, $D$. dipsaci, used as a positive control. Relationships for body length of the two nematode species and life stage were unaffected by rearing on plant hosts compared with carrot disks. Then plant-reared J4 individuals of both nematode species were used to determine the effect of temperature $\left(17,22\right.$, and $\left.27^{\circ} \mathrm{C}\right)$ on life-

stage progression and minimum generation time with yellow pea. At 17 and $22^{\circ} \mathrm{C}, D$. weischeri $\mathrm{J} 4$ individuals progressed to only the adult stage whereas, at $27^{\circ} \mathrm{C}$, the minimum generation time from $\mathrm{J} 4$ to $\mathrm{J} 4$ was 30 days or 720 growing degree-days. The minimum generation time for $D$. dipsaci was 24,18 , and 22 days or 336,342 , and 528 growing degree-days at 17,22 , and $27^{\circ} \mathrm{C}$, respectively. The results indicate that development of $D$. weischeri is temperature dependent and reproduction is unlikely on yellow pea in the Canadian Prairies, where mean daily air temperatures of $27^{\circ} \mathrm{C}$ are rare and not sustained.
\end{abstract}

The nematode genus Ditylenchus (Anguinidae, Tylenchida) has about 80 recognized species, with the greatest variety of feeding habits and behaviors. Among these species, migratory endoparasites such as Ditylenchus dipsaci, D. destructor, D. gigas, and D. weischeri invade either the upper (stems, leaves, flowers, and seed) or lower (roots and bulbs) parts of many species of wild and cultivated plants worldwide (Chizhov et al. 2010; Plowright et al. 2002; Sturhan and Brzeski 1991; Vovlas et al. 2011). These nematodes live in soil or dry infested plant material and penetrate plant organs via stomata, petioles, buds, or epidermal fractures or wounds. Once in the host plant, the nematode individuals break down the middle lamella, cause separation of the cells, and colonize parenchymal tissues, where they feed by puncturing and sucking cell contents, resulting in compromised growth and secondary pathogen damage (Duncan and Moens 2013; Jones and De Waele 1990; Krusberg 1961; Sturhan and Brzeski 1991).

The occurrence of the stem nematode $D$. weischeri (Chizhov et al. 2010) parasitizing creeping thistle (Cirsium arvense L.) on the Canadian Prairies (Tenuta et al. 2014) and species-specific conventional and real-time polymerase chain reaction (PCR) methods for differentiation of the related pest, D. dipsaci (Kühn) Filipjev, were recently reported (Madani et al. 2015). Most recently, D. weischeri was shown to develop prolifically on creeping thistle but not on lentil (Lens culinaris Medikus), chickpea (Cicer arietinum L.), common bean (Phaseolus vulgaris L.), garlic (Allium sativum L.), spring wheat (Triticum aestivum L.), and canola (Brassica napus L.) under greenhouse conditions (Hajihassani et al. 2016). However, two of five yellow pea (Pisum sativum L.) varieties examined were poor hosts, allowing survival but not reproduction of the nematode. Resolving whether or not $D$. weischeri can parasitize yellow pea is important because creeping thistle is commonly present in yellow pea fields in the Canadian Prairies. Additionally, understanding the potential concern regarding $D$. weischeri parasitizing yellow pea under warming climate conditions is important.

Chizhov et al. (2010) reported that D. weischeri likely produced three or four generations on creeping thistle per season near Moscow,

Corresponding author: M. Tenuta; E-mail: mario.tenuta@umanitoba.ca

Accepted for publication 10 October 2016.

(c) 2017 The American Phytopathological Society
Russia. More is known about life-stage development and generation production of the closely related pest nematode, D. dipsaci (Hooper 1972; Yuksel 1960). Egg production occurs over 7 days, secondstage juveniles (J2) emerge from eggs after 2 days; then, molting to third-stage juveniles (J3) occurs 3 days later, molting to fourthstage juveniles (J4) after 4 days, and adults are present 3 days later at $15^{\circ} \mathrm{C}$ (Yuksel 1960).

Temperature affects life-stage development and behavior of plantparasitic nematodes, with different species and races having optimum temperatures for penetration (Griffith et al. 1997), feeding (Boag 1980), survival (Miyagawa and Lear 1970), and reproduction (Acosta and Malek 1979; Thompson et al. 2015). Thus, not surprisingly, temperature is also an important factor in controlling generation time of a nematode (Trudgill et al. 2005). For example, Mizukubo and Adachi (1997) examined the effect of temperature on egg production and generation time of Pratylenchus penetrans on clover roots. They reported generation times of 46, 38, 28, 26, and 22 days at $17,20,25,27$, and $30^{\circ} \mathrm{C}$, respectively. Tenente and Evans (1998) reported that the generation time of the teasel (Dipsacus spp.) race of D. dipsaci was 21 to 28 days at $20^{\circ} \mathrm{C}$ and 28 to 34 days at $15^{\circ} \mathrm{C}$. The development and multiplication of $D$. dipsaci in white clover (Trifolium repens L.) and alfalfa (Medicago sativa L.) plants was directly related to temperature (Griffin 1968; Griffith et al. 1997). De Waele and Wilken (1990) reported temperature of $28^{\circ} \mathrm{C}$ optimal for hatching, development, and egg production of the potato rot nematode, $D$. destructor. However, as temperature decreased from 28 to $16^{\circ} \mathrm{C}$, generation time increased from 6 to 12 days.

Determination of juvenile life stages of plant-parasitic nematodes is often done using morphometric measures. For example, with many nematode species, progression from $\mathrm{J} 2$ to $\mathrm{J} 4$ stages results in increasing body length (Barraclough and Blackith 1962). However, variation in morphometric measures of nematodes can vary with geographical location (Brown and Topham 1985; Khan et al. 2012; Townshend 1991) and differing hosts (Foot and Wood 1982; Tarte and Mai 1976). For instance, Foot and Wood (1982) reported that males and females of a field population of $D$. destructor were shorter than those cultivated on fungi Alternaria tenuis and A. solani. Therefore, relation of body length to nematode life stages should be determined for specific rearing conditions and populations of plant-parasitic nematodes.

In the current study, pure inoculums of $D$. weischeri and $D$. dipsaci $\mathrm{J} 4$ were required to be produced. To distinguish different juvenile stages of the nematodes, it was also necessary to establish relations 
of the body length to juvenile life stages. Because host or conditions under which plant-parasitic nematodes are reared can affect body size and, thus, juvenile life-stage identification, we tested the hypothesis that rearing $D$. weischeri and $D$. dipsaci on the live plants of creeping thistle and garlic, respectively, and carrot disk cultures had no effect on life-stage morphometric measures. Therefore, the purposes of the current study were to determine (i) the effect of rearing conditions on morphometrics of $D$. weischeri and $D$. dipsaci development life stages; (ii) the effect of temperatures of 17,22 , and $27^{\circ} \mathrm{C}$ on the ability of $D$. weischeri to penetrate and reproduce on 'Agassiz' yellow pea; and (iii) the effect of temperature on the generation time of the nematodes on yellow pea. D. dipsaci, known to reproduce on yellow pea, was used as a positive control.

\section{Materials and Methods}

Nematode sources and species determination. D. weischeri was obtained from naturally infested creeping thistle in a field at the University of Manitoba Glenlea Research Station south of Winnipeg, Manitoba, Canada. D. dipsaci was obtained from garlic cloves from a commercial field in southern Ontario. The nematodes were identified morphologically and morphometrically (Tenuta et al. 2014), then examined by conventional PCR using species-specific $h s p 90$ and internal transcribed spacer (ITS) gene primer sets (Madani et al. 2015).

Nematode rearing. $D$. weischeri and $D$. dipsaci were reared monoxenically on carrot disks (A. Hajihassani and M. Tenuta, unpublished). Briefly, $80 \mathrm{~J} 4$ were first surface sterilized in sequential solutions of streptomycin sulfate $(4,000 \mathrm{mg} /$ liter $)$, mercuric chloride $(1,000 \mathrm{mg} / \mathrm{liter})$, and sterile distilled water. Then, they were pipetted to 5 -mm-thick carrot disks sterilized in $95 \%$ ethanol in petri dishes and incubated for 3 months at $23 \pm 1{ }^{\circ} \mathrm{C}$. To prepare a uniform population of $\mathrm{J} 4$ individuals, $D$. weischeri and $D$. dipsaci raised on carrot disks were then transferred to creeping thistle and garlic plants, respectively, in a growth chamber at $23 \pm 1{ }^{\circ} \mathrm{C}$ and $22 \%$ relative humidity with $16 \mathrm{~h}$ of light and $8 \mathrm{~h}$ of darkness. For this purpose, four segmented rhizomes of creeping thistle and four garlic cloves (artichoke garlic) were planted to pots $(12.5 \mathrm{~cm}$ in diameter by $12 \mathrm{~cm}$ in height) filled with equal parts of autoclaved nursery soil and growing mix (Sungro Horticulture, Seba Beach, AB, Canada). About 1 week after planting, emerged plants were inoculated with about 1,000 fresh mixed developmental stages of D. weischeri or D. dipsaci in $40 \mu \mathrm{l}$ of $1.5 \%$ carboxymethyl cellulose (Sigma-Aldrich Co., Oakville, ON, Canada) suspension distributed to three locations $5 \mathrm{~mm}$ from stems and deep in soil. Plants were watered every 2 days until natural senescence occurred, about 65 to 75 days after planting.

Determination of nematode life stages and effect of rearing conditions. $D$. weischeri and $D$. dipsaci were reared on carrot disks or on creeping thistle and garlic, respectively, as described previously. The plant pots and carrot disk plates were arranged in a completely randomized design with six replications, then incubated in a growth chamber at $23 \pm 1^{\circ} \mathrm{C}$. The nematodes were recovered from carrot disks and plants using a Baermann extraction pan method (Whitehead and Hemming 1965). The technique employed pans (18 $\mathrm{cm}$ in diameter) with one layer of laboratory tissue (Kimwipe; Kimberly-Clark, Roswell, GA) on a steel mesh (2-mm grid) supported by 5 -mm-thick plastic rings. Carrot disks or plant stems and leaves were chopped to approximately 0.5 - to $1-\mathrm{cm}$ segment lengths and placed on an extraction pan filled with tap water to just cover the plant material on the laboratory tissue. After $72 \mathrm{~h}$ of incubation at room temperature, the water was passed through a 500 -mesh $(25-\mu \mathrm{m}$ pore $)$ sieve to trap vermiform development stages. Eggs were recovered by blending material remaining on the extraction pan with sucrose (30\% [wt/vol]) for $30 \mathrm{~s}$ and centrifugation at $1,500 \times g$ for $4 \mathrm{~min}$, then collected on a 625 -mesh $(20-\mu \mathrm{m}$ pore) sieve (Eisenback 2000$)$. For each rearing treatment, $20 \mathrm{~J} 2$ and 30 individuals each for egg, J3, $\mathrm{J} 4$, male, and female (170 overall individuals) of either nematode species were hand picked from the recovered nematodes, then transferred to a drop of water on a glass slide and gently heat killed. Individuals were observed using a compound microscope (BX-51; Olympus, Tokyo). Body length, width, and ratio "a" (body length/width) (Hooper 1972) of vermiform stages were determined using a digital camera (Qcolor3; Olympus) and image processing software (ImagePro Plus 6.2; Media Cybernetics, Rockville, MD). In addition, genital primordial development (size, position, and number of genital nuclei) of juveniles were examined (Anderson and Darling 1964; Perry 1976). Adult individuals were differentiated by presence of a spicule or vulva. This experiment was conducted twice.

Effect of temperature on nematode penetration and development. Polyethylene pots ( $10 \mathrm{~cm}$ in diameter by $9.5 \mathrm{~cm}$ in height) filled with equal parts autoclaved nursery soil of loam texture and growing mix of peat moss, perlite, and vermicullite were prepared. Seed of Agassiz yellow pea (previously shown to allow slight reproduction of $D$. weischeri) (Hajihassani et al. 2016) were surface sterilized for $5 \mathrm{~min}$ in $20 \mathrm{ml}$ of $1.0 \%$ sodium hypochlorite, rinsed in sterile distilled water, and germinated on damp sterile filter paper in petri dishes at $24^{\circ} \mathrm{C}$ for up to 3 days. When hypocotyls and roots of $2 \mathrm{~cm}$ in length emerged, each seed was placed $2 \mathrm{~cm}$ below the soil surface of one pot, and $300 \mathrm{~J} 4$ of $D$. weischeri or D. dipsaci in $40 \mu \mathrm{l}$ of $1.5 \%$ carboxymethyl cellulose suspension were added to the base of each hypocotyl and covered with moistened soil. The $D$. weischeri and $D$. dipsaci J4 were obtained from growth-chambergrown creeping thistle and garlic plants, respectively, as described previously. Pots were then placed in three separate growth chambers (Conviron CMP3244; Conviron Products Company, Winnipeg, MB) maintained continuously at 17,22 , and $27^{\circ} \mathrm{C}$ respectively, with $16 \mathrm{~h}$ of light and $8 \mathrm{~h}$ of darkness. The lower temperature was selected as being similar to the mean daily air temperature in mid- to late summer in areas where yellow pea is grown on the Canadian Prairies. The high temperature was selected because we were interested in whether $D$. weischeri could reproduce at a temperature higher than $25^{\circ} \mathrm{C}$ (at which it previously was unable to reproduce) (Hajihassani et al. 2016). In each growth chamber, groups of two inoculated plants were placed next to each other. Each pot was covered with a transparent polyethylene bag for the first 3 days to maintain soil surface moisture. Enough pots were set up at each temperature to allow destructive sampling of six plants inoculated with either nematode every 2 days up to 35 days, when a new generation of J4 individuals appeared.

Light intensity at the top of plants was between 1,300 and $1,400 \mu \mathrm{E} / \mathrm{m}^{2} / \mathrm{s}$ in each chamber using a photometer (LI-185B; Li-Cor, Lincoln, NE), a photosynthetic active radiation sensor (Quantum Q2597; Li-Cor), and adjustment of lamp height. The temperature of each chamber was verified using a humidity and temperature data logger (Extech RHT10; USB Data Logger, Waltham, MA) placed $20 \mathrm{~cm}$ above the pots and set to record every $2 \mathrm{~h}$ throughout the experiment. The mean temperature in each of the growth chambers was $17 \pm 0.6,22 \pm 0.5$, and $27 \pm 0.6^{\circ} \mathrm{C}$ and humidity varied between growth chambers from 22 to $45 \%$. Pots were watered lightly every other day, with care to not result in drainage from pots. Aerial plant parts were misted daily with tap water to not restrict nematode migration on plant surfaces. Misting was done with care to prevent washing the nematodes off the plant surfaces. On each sampling day, six plants of each treatment group were randomly taken, three of which were harvested destructively to recover the root system; however, only the proximal $5 \mathrm{~cm}$ of the root system was retained. Roots and stems were rinsed with running tap water to remove soil and plant surface nematodes, and then extracted for eggs and vermiform life stages as described previously. Adults were differentiated as described previously and males and females were not counted separately. Body length of nematodes was used to determine juvenile life stages; however, if there was any doubt about stage identification, position and state of gonads was used (Anderson and Darling 1964; Perry 1976). Penetration of the nematodes to initiate development on the host was assessed from recovery of nematodes 1 and 5 days after inoculation (DAI). We acknowledge that time to complete development stages varies with individuals in a population. Further, age of J4 individuals added to yellow pea plants likely differed. Thus, in the current study, we report a minimum development time for progression of development stages between the first occurrence of a stage and that of the subsequent stage. Sampling for 
recovery of life stages occurred every 2 days; thus, first occurrence of a stage could have happened on a day not sampled. Therefore, when two or more nematodes occurred for the first time, it was assumed that at least one individual would have been recovered the previous day.

The three other plants obtained on each sampling day were used to visualize nematode development stages in plant tissues. Roots were washed free of soil using tap water, then soaked in $1 \% \mathrm{NaOCl}$ (wt/vol) for 4 min with occasional hand agitation and a final rinse of tap water. The nematodes in roots were stained by boiling for $30 \mathrm{~s}$ in $20 \mathrm{ml}$ of distilled water containing $300 \mu \mathrm{l}$ of $3.5 \%$ (wt/vol) acid fuchsin. Sectioned stems and leaves were cleared in lactophenol (equal parts glycerol, lactic acid, phenol, and water) and ethanol (1:2 [vol/vol]) for $48 \mathrm{~h}$, with one change of the solution to remove pigments from the tissues. Depending on the amount of tissue, cleared stems and leaves were then boiled for 30 to $40 \mathrm{~s}$ in 20 to $30 \mathrm{ml}$ of distilled water, respectively, containing $1 \mathrm{ml}$ of $3.5 \%$ (wt/vol) acid fuchsin to stain nematodes. After staining, all materials were rinsed in distilled water and destained in lactophenol for $24 \mathrm{~h}$ with one change of the solution. Visualization of nematode development stages in the plant tissues was done with a stereo microscope (SZ 61; Olympus, Tokyo) at $\times 20$ to $\times 90$ magnification, and images were captured using a digital camera (Qcolor3; Olympus). Enumeration of all nematodes in tissues and their lengths presented challenges; therefore, visualization was for qualitative purpose to confirm penetration of tissues with the nematodes. The experiment was conducted twice.

Statistical analysis. To examine whether the measurement values of specimens reared on carrot disks differed from those reared on plants, a two-sample $t$ test assuming equal variances was performed using SAS (version 9.3; SAS Institute Inc., Cary, NC). An $\alpha \leq 0.05$ was used to infer statistical differences between comparisons.

In the temperature development study, data on the number of penetrated J4 were analyzed using a two-way analysis of variance mixed-model approach in SAS, where temperature, repeat of the experiment, and their interaction were considered fixed effects and replication nested within experimental repeat was considered a random effect. Prior to each analysis and to meet the assumption for normality of residuals, data sets were examined using the ShapiroWilk test and inspected for outliers. Raw data sets were also checked for homogeneity of variances based on the Akaike information criterion. Significant differences between treatment means were compared using Fisher's protected least significant difference test and the pdmix 800 macro (Saxton 1998). Accumulated growing degree-days was determined using the formula degree-days $=(T-$ $t) \times$ DAI, where $T=$ growth chamber temperature $\left({ }^{\circ} \mathrm{C}\right)$ and $t=$ base temperature $\left({ }^{\circ} \mathrm{C}\right.$ ) (Singh and Sharma 1994). A base temperature of $3^{\circ} \mathrm{C}$ was used for $D$. dipsaci according to Griffith et al. (1997). The base temperature of $D$. weischeri has not been reported but, lacking information, we assumed it to be similar to that of $D$. dipsaci.

\section{Results}

Nematode identification. Morphological examinations of D. weischeri and D. dipsaci, including shape of stylet, spicules, bursa, vulva, and tail in adults as well as morphometrics and molecular analysis, were in accordance with those reported previously (Chizhov et al. 2010; Madani et al. 2015; Tenuta et al. 2014).

Effect of rearing conditions on nematodes body size. Juvenile stages of the nematodes obtained from creeping thistle, garlic, and carrot disk were placed in successive groupings of longer body length of individuals. Generally, the body length of juvenile stages was slightly greater for the nematodes reared on plants than carrot disks (Table 1). However, body length was able to characterize juvenile stage and, except for some $\mathrm{J} 2$ and $\mathrm{J} 3$ individuals of $D$. weischeri reared on carrot disk and $D$. dipsaci reared on garlic, samples did not overlap in measurements but were distinct and easily placed into development life stage. With regard to separation of $\mathrm{J} 2$ and $\mathrm{J} 3$ individuals on the few occasions when body length of the stages overlapped, $\mathrm{J} 2$ stage was assumed to have a shorter genital perimordium than $\mathrm{J} 3$ stage and contained fewer germinal nuclei. In addition, J3 individuals were identified as having anterior and posterior gonad primordia. The body length discrimination of development life stages obtained in this study was used in the following temperature development study to assign juvenile life stage of recovered individuals.

The resulting average body lengths of the $\mathrm{J} 2, \mathrm{~J} 3$, and $\mathrm{J} 4$ life stages of recovered D. weischeri were 457 (309 to 545), 651 (558 to 750),

Table 1. Mean morphometric characteristics of Ditylenchus weischeri and D. dipsaci development stages reared on creeping thistle and garlic, respectively, and both on carrot disks

\begin{tabular}{|c|c|c|c|c|c|c|c|c|c|c|}
\hline \multirow{4}{*}{$\frac{\text { Assigned stage }^{\mathrm{y}}}{\mathrm{J} 2}$} & \multicolumn{10}{|c|}{ Measurement $(\mu \mathrm{m})^{\mathrm{x}}$} \\
\hline & \multicolumn{5}{|c|}{ D. weischeri } & \multicolumn{5}{|c|}{ D. dipsaci } \\
\hline & \multicolumn{2}{|c|}{ Creeping thistle } & \multicolumn{2}{|c|}{ Carrot disk } & \multirow{3}{*}{$\begin{array}{c}\boldsymbol{t} \text { test }^{\mathbf{z}} \\
\qquad \mathrm{ns}\end{array}$} & \multicolumn{2}{|c|}{ Garlic } & \multicolumn{2}{|c|}{ Carrot disk } & \multirow[t]{2}{*}{$t$ test $^{\mathrm{z}}$} \\
\hline & & & & & & & & & & \\
\hline Body length & $457 \pm 66^{x}$ & $309-545^{y}$ & $446 \pm 75$ & $325-549$ & & $477 \pm 63$ & $321-568$ & $434 \pm 68$ & $325-537$ & $*$ \\
\hline Body width & $14 \pm 1$ & $12-16$ & $14 \pm 2$ & $11.6-16.9$ & ns & $15 \pm 2$ & $12-18$ & $15 \pm 2$ & $12-18$ & ns \\
\hline Ratio a & $32.5 \pm 3$ & $26.1-36.9$ & $31.3 \pm 3$ & $26.0-25.9$ & ns & $30.9 \pm 3$ & $24.5-35.9$ & $28.5 \pm 3$ & $22.6-32.5$ & $*$ \\
\hline \multicolumn{11}{|l|}{$\mathrm{J} 3$} \\
\hline Body length & $651 \pm 56$ & $558-750$ & $636 \pm 51$ & $542-755$ & ns & $660 \pm 62$ & $558-745$ & $650 \pm 68$ & $553-760$ & $\mathrm{~ns}$ \\
\hline Body width & $19 \pm 1$ & $16-20$ & $18 \pm 2$ & $16-23$ & $*$ & $21 \pm 3$ & $18-26$ & $19 \pm 2$ & $17-26$ & $* *$ \\
\hline Ratio a & $36.1 \pm 3$ & $31.6-46.2$ & $35.0 \pm 2$ & $27.7-39.5$ & ns & $31 \pm 2$ & $27-36$ & $34.1 \pm 3$ & $29-40.1$ & $* * *$ \\
\hline \multicolumn{11}{|l|}{$\mathrm{J} 4$} \\
\hline Body length & $875 \pm 83$ & $771-1,025$ & $812 \pm 40$ & 758-971 & $* * *$ & $900 \pm 99$ & $768-1,091$ & $874 \pm 62$ & 791-1,034 & ns \\
\hline Body width & $20 \pm 2$ & $17-23$ & $21 \pm 2$ & $17-24$ & $\mathrm{~ns}$ & $26 \pm 2$ & $21-30$ & $25 \pm 2$ & $20-29$ & $*$ \\
\hline Ratio a & $43.5 \pm 6$ & $34.8-53.8$ & $39.8 \pm 4$ & $32.3-47.3$ & $* *$ & $34 \pm 3$ & $29.1-40.2$ & $35.5 \pm 2$ & $31.4-40.5$ & $*$ \\
\hline \multicolumn{11}{|l|}{ Male } \\
\hline Body length & $1224 \pm 82$ & $1,059-1,374$ & $1,139 \pm 126$ & $946-1,384$ & $* *$ & $1,331 \pm 112$ & $1,142-1,521$ & $1,173 \pm 100$ & $994-1,367$ & $* *$ \\
\hline Body width & $26.3 \pm 1$ & $23-28$ & $25 \pm 2$ & $21-27$ & $*$ & $31 \pm 2$ & $28-34$ & $30 \pm 3$ & $24-35$ & $\mathrm{~ns}$ \\
\hline Ratio a & $47.8 \pm 2$ & $44.3-54.0$ & $45.4 \pm 4$ & $36.8-52.7$ & $*$ & $43.1 \pm 3$ & $36.5-50.7$ & $391 \pm 4$ & $32.6-49.9$ & $* * *$ \\
\hline \multicolumn{11}{|l|}{ Female } \\
\hline Body length & $1,259 \pm 74$ & $1,139-1,425$ & $1,178 \pm 141$ & $938-1410$ & $* *$ & $1,379 \pm 109$ & $1,116-1,580$ & $1,218 \pm 135$ & $1,035-1,490$ & $* *$ \\
\hline Body width & $31 \pm 1$ & 29-33 & $29 \pm 3$ & $21-34$ & $* *$ & $32 \pm 2$ & 29-39 & $31 \pm 2$ & $25-35$ & $*$ \\
\hline Ratio a & $40.2 \pm 2$ & $37.4-45.5$ & $40.6 \pm 4$ & $33.9-49.8$ & ns & $42.7 \pm 3$ & $37.0-47.6$ & $39.6 \pm 4$ & $31.8-45.6$ & $* * *$ \\
\hline
\end{tabular}

Each value represents the mean \pm standard error $(n=30)$ or range (minimum-maximum) of values.

${ }^{y} \mathrm{~J} 2, \mathrm{~J} 3$, and $\mathrm{J} 4=$ second-, third-, and fourth-stage juvenile, respectively; ratio a = body length to body width ratio.

${ }^{\mathrm{z}}$ Comparison of means of morphometric variables between rearing hosts using $t$ tests; ns $=$ no significant difference; $*, * *$, and $* * *$ indicate $P<0.05,0.01$, and 0.001 , respectively. 
and 875 (771 to 1,025$) \mu \mathrm{m}$, respectively, on creeping thistle and 446 (325 to 549), 636 (542 to 755 ), and 812 (325 to 971) $\mu \mathrm{m}$, respectively, on carrot disk. Body lengths were significantly longer by $8 \%$ for $\mathrm{J} 4$ and $7 \%$ for male and female individuals from creeping thistle than carrot disk. Body width of $D$. weischeri from creeping thistle was significantly slightly greater than from carrot disk. Only ratio a of $D$. weischeri $\mathrm{J} 4$ and male individuals from carrot disk was less than that from creeping thistle (Table 1).

The resulting average body lengths of the $\mathrm{J} 2, \mathrm{~J} 3$, and $\mathrm{J} 4$ life stages of $D$. dipsaci recovered were 477 (range 321 to 568), 660 (558 to 745 ), and 900 (768 to 1,091) $\mu \mathrm{m}$, respectively, on garlic and 434 (325 to 537), 650 (553 to 760), and 847 (791 to 1,034) $\mu \mathrm{m}$, respectively, on carrot disk. Body lengths were significantly longer by $10 \%$ for $\mathrm{J} 2$ and $13 \%$ for male and female individuals from garlic than carrot disk. Body width was significantly wider for $\mathrm{J} 3$, J4, and female individuals from garlic than carrot disk. There wasn't a consistent effect of rearing conditions on ratio a of juvenile stages with the value being greater for $\mathrm{J} 2$ and smaller for $\mathrm{J} 3$ and $\mathrm{J} 4$ individuals. For adults, ratio a was significantly greater for individuals from garlic than carrot disk (Table 1).

Effect of temperature on nematode penetration. D. weischeri. At 1 DAI of yellow pea plants, no significant $(P<0.05)$ difference in the nematode recovery was observed among the three temperatures tested (Table 2). However, nematode penetration, as apparent from the number of $\mathrm{J} 4$ recovered, was greater $(P=0.045)$ for the repeat

Table 2. Effect of temperature on penetration of Ditylenchus weischeri and $D$. dipsaci fourth-stage juveniles (J4) into Agassiz yellow pea seedling 1 and 5 days after addition

\begin{tabular}{|c|c|c|c|}
\hline \multirow[b]{2}{*}{ Days, trial $^{\mathrm{Z}}$} & \multirow[b]{2}{*}{ Temperature $\left({ }^{\circ} \mathrm{C}\right)$} & \multicolumn{2}{|c|}{ Number of J4/planty } \\
\hline & & D. weischeri & D. dipsaci \\
\hline \multicolumn{4}{|l|}{$1 \mathrm{DAI}$} \\
\hline \multirow[t]{3}{*}{ Both } & 17 & $42 \pm 6 a$ & $56 \pm 5 b$ \\
\hline & 22 & $50 \pm 3 a$ & $72 \pm 4 a$ \\
\hline & 27 & $38 \pm 4 a$ & $48 \pm 3 b$ \\
\hline \multirow[t]{4}{*}{ Trial 1} & 17 & $35 \pm 8$ & $53 \pm 3$ \\
\hline & 22 & $45 \pm 4$ & $74 \pm 5$ \\
\hline & 27 & $33 \pm 5$ & $48 \pm 6$ \\
\hline & All & $38 \pm 5 \mathrm{~B}$ & $58 \pm 4$ \\
\hline \multirow[t]{4}{*}{ Trial 2} & 17 & $49 \pm 3$ & $59 \pm 5$ \\
\hline & 22 & $56 \pm 4$ & $71 \pm 3$ \\
\hline & 27 & $42 \pm 3$ & $48 \pm 4$ \\
\hline & All & $49 \pm 4 \mathrm{~A}$ & $59 \pm 3$ \\
\hline \multicolumn{4}{|l|}{$P<F$} \\
\hline Temperature & $\ldots$ & 0.0504 & 0.0103 \\
\hline Trial & $\ldots$ & 0.0452 & 0.9142 \\
\hline Temperature $\times$ trial & $\ldots$ & 0.9283 & 0.7488 \\
\hline \multicolumn{4}{|l|}{5 DAI } \\
\hline \multirow[t]{3}{*}{ Both } & 17 & $69 \pm 3 b$ & $120 \pm 5$ \\
\hline & 22 & $108 \pm 6 a$ & $162 \pm 12$ \\
\hline & 27 & $94 \pm 7 \mathrm{a}$ & $113 \pm 3$ \\
\hline \multirow[t]{4}{*}{ Trial 1} & 17 & $78 \pm 4$ & $114 \pm 7 b$ \\
\hline & 22 & $108 \pm 7$ & $192 \pm 10 \mathrm{a}$ \\
\hline & 27 & $84 \pm 3$ & $117 \pm 6 b$ \\
\hline & Mean & $90 \pm 4$ & $141 \pm 10 \mathrm{~A}$ \\
\hline \multirow[t]{4}{*}{ Trial 2} & 17 & $61 \pm 3$ & $127 \pm 10 b$ \\
\hline & 22 & $107 \pm 5$ & $131 \pm 8 b$ \\
\hline & 27 & $105 \pm 6$ & $110 \pm 7 b$ \\
\hline & Mean & $91 \pm 4$ & $123 \pm 12 \mathrm{~B}$ \\
\hline \multicolumn{4}{|l|}{$P<F$} \\
\hline Temperature & $\ldots$ & 0.0044 & 0.0002 \\
\hline Trial & $\ldots$ & 0.8945 & 0.0126 \\
\hline Temperature $\times$ trial & $\ldots$ & 0.1243 & 0.0016 \\
\hline
\end{tabular}

y Each value represents the mean \pm standard error of three replicates for either trial 1 and 2, and six replicates for both trials and mean. Any two means in the same column with a letter in common are not significantly different according to Fisher's protected least significant difference test $(P=0.05)$. Lowercase letters refer to temperature or trial effects and uppercase letters refer to the temperature-trial interaction effect.

${ }^{\mathrm{z}} \mathrm{DAI}=$ day after inoculation. trial 1 DAI (Table 2). Differences between repeats may have been due to differences in soil moisture and humidity of growth chambers that were not controlled for. At 5 DAI, only the effect of temperature $(P<0.0044)$ was significant, with nematode recovery greater at $22^{\circ} \mathrm{C}$ (36\% recovery) and $27^{\circ} \mathrm{C}(31 \%)$ than $17^{\circ} \mathrm{C}(23 \%)$. Microscopic examination 1 DAI showed that the $D$. weischeri J4 were first detected in the base of the stems, including hypocotyl and epicotyl of infested seedlings, migrating upward.

D. dipsaci. Recovery of individuals $1 \mathrm{DAI}$ was higher at $22^{\circ} \mathrm{C}$ than at the other temperatures (Table 2). At 5 DAI, there was a significant temperature-repeat trial interaction. The interaction resulted because recovery increase for $22^{\circ} \mathrm{C}$ compared with 17 and $27^{\circ} \mathrm{C}$ was greater in the first trial than in the repeat trial. The interaction effect precluded establishing an effect of temperature on nematode recovery 5 DAI. A similar pattern was found for the effect of repeat trial because the number of recovered nematodes was numerically higher at 22 than 17 and $27^{\circ} \mathrm{C}$. Microscopic examination showed that the $\mathrm{J} 4$ were first observed in the base of yellow pea stems and embryonic first root (hypocotyl) 1 DAI at all three temperatures tested. Individuals did not position just beneath the epidermis of the stem; rather, they resided in the stem cortex tissue closer to the vascular bundles.

Effect of temperature on nematode development. $\quad$ D. weischeri. Recovered J4 individuals peaked 7 and $9 \mathrm{DAI}$ at 17 and $22^{\circ} \mathrm{C}$, respectively, then declined with time. The decline coincided with a rise in adult individuals but these did not result in recovery of eggs or $\mathrm{J} 2$ and $\mathrm{J} 3$ individuals from plants (Fig. 1). At $27^{\circ} \mathrm{C}$, the recovered $\mathrm{J} 4$ numbers peaked $5 \mathrm{DAI}$, with a rise in the recovery of adults. The peak recovery and subsequent decline of successive development stages coincided with rise in recovery of the next life stage. Egg and J2 and $\mathrm{J} 3$ individuals were recovered 12,20 , and 25 DAI and $\mathrm{J} 4$ individuals were again recovered 30 DAI (Fig. 1; Table 3), indicating that the minimum generation time required for $D$. weischeri to complete a generation from the first observation of $\mathrm{J} 4$ in the plant to the $\mathrm{J} 4$ of the second generation was 30 days.

At $27^{\circ} \mathrm{C}$, the first presence of male and female individuals in the stems (Fig. 2A to C) was observed about 5 DAI (Table 3). Eggs were first observed in the base of the stems (Fig. 2A) 12 DAI (Table 3) and then throughout stems (Fig. 2D). The J2 and J3 life stages were observed in plant tissues 20 and $25 \mathrm{DAI}$, respectively, and the J3 developed to the $\mathrm{J} 4$ in about 5 days (Table 3 ). Total minimum accumulated degree-days above the base temperature of $3^{\circ} \mathrm{C}$ required to obtain adult, egg, J2, J3, and J4 stages was 120, 1,168, 192, 120, and 120, respectively. The minimum accumulated growing degree-days for $D$. weischeri to complete one generation was about 720 degree-days (Table 3).

D. dipsaci. The recovery of all development stages of $D$. dipsaci from yellow pea plants varied with temperature (Fig. 3). Recovered $\mathrm{J} 4$ individuals peaked 7,5 , and $7 \mathrm{DAI}$ at 17,22 , and $27^{\circ} \mathrm{C}$, respectively, and then declined with time. The greatest recovery of any development stage was at $22^{\circ} \mathrm{C}$, followed by 17 and then $27^{\circ} \mathrm{C}$. At all three temperatures examined, greatest recovery of adults occurred 15, 9, and 13 DAI (Fig. 3). The J4 individuals from the second generation were again recovered, at the earliest, 24, 18, and 22 DAI at 17,22 , and $27^{\circ} \mathrm{C}$, respectively.

At all temperatures tested, J4 individuals were observed inside the root and base of stems, however, the number of nematodes in the stems appeared to be much greater than that from roots. As time progressed, $D$. dipsaci migrated up from the initial inoculation point at the base of stem and infested upper regions of the stem. The nematode development (progression from $\mathrm{J} 4$ to adults to second generation of J4) was fastest at $17^{\circ} \mathrm{C}$ than 22 and $27^{\circ} \mathrm{C}$. Similar findings were observed for the minimum time requirements for completion of each life stage (Table 3). D. dipsaci of different developmental stages were present in various plant tissues including leaves. The minimum accumulated growing degree-days required for the nematode to complete a generation was 336,342 , and 528 degree-days at 17,22 , and $27^{\circ} \mathrm{C}$, respectively (Table 3 ).

\section{Discussion}

The current study demonstrated the ability to discriminate juvenile development stages of $D$. weischeri and $D$. dipsaci based on body 
length. This finding is similar to the observations of Barraclough and Blackith (1962) and Perry (1976), who stated that juvenile stages of D. dipsaci from a plant species can be separated by length alone. Also, the current study is the first examination of the effect of temperature on penetration and in planta development of the recently described stem nematode $D$. weischeri.

Effect of rearing conditions on $D$. weischeri and $D$. dipsaci body size. In the current study, the juvenile life stages were clearly separated by their body length, though overlap in body lengths of the $\mathrm{J} 2$ and $\mathrm{J} 3$ stages for $D$. weischeri reared on carrot disk and $D$. dipsaci reared on garlic were observed. Body length, body width, and ratio a of males and females reported here are nearly similar to those given by Tenuta et al. (2014). They reported $D$. weischeri obtained from creeping thistle to have average body length of 1,249 (range $1,244$ to 1,254$) \mu \mathrm{m}$ for males and $1,202(1,049$ to 1,355$) \mu \mathrm{m}$ for females, compared with $1,224(1,059$ to 1,374$)$ and $1,259(1,139$ to $1,425) \mu \mathrm{m}$, respectively, in the current study. The adult body length difference between studies was less than $5 \%$.

In the current study, juvenile and adult individuals of $D$. weischeri and $D$. dipsaci reared on carrot disks were slightly shorter and thinner than those from creeping thistle and garlic for the respective nematode. Tarte and Mai (1976) reported that $P$. penetrans from pea plants was shorter and wider than from callus tissue of alfalfa. We observed that ratio a of both nematodes was slightly less from carrot disks than plants. Others have reported variation in the body size of nematode developmental stages to be a consequence of host-induced differences (Doucet et al. 2001; Foot and Wood 1982; Fortuner and Quénéhervé 1980; Tarte and Mai 1976). In the current study, hostinduced differences were small because body length of stages reared on plants or carrot disks were nearly similar. Thus, body length of the nematodes can be used with care to separate juvenile life stages regardless of rearing conditions.

Effect of temperature on $\boldsymbol{D}$. weischeri development. Temperature plays a significant role in regulating the life-cycle of plantparasitic nematodes, including Ditylenchus spp. (Griffith et al. 1997). In the current study, temperature affected the penetration of the $\mathrm{J} 4$ at 5 DAI. At 22 and $27^{\circ} \mathrm{C}$, increase in the $\mathrm{J} 4$ penetration in the first 5 days was likely due to migration of added $\mathrm{J} 4$ from the point of inoculation in soil to harvested plant components. Our finding is comparable with observations of Castillo et al. (1996), who reported that $P$. thornei penetration into chickpea roots was higher at 20 and $25^{\circ} \mathrm{C}$ than that at $15^{\circ} \mathrm{C}$. We found that $D$. weischeri adults failed to produce eggs within plant tissues at 17 and $22^{\circ} \mathrm{C}$. In contrast, nematode reproduction was observed at $27^{\circ} \mathrm{C}$. In a previous host preference study, D. weischeri reproduced slightly on yellow pea but prolifically on creeping thistle at $25^{\circ} \mathrm{C}$ (Hajihassani et al. 2016). To our knowledge, this is the first report that
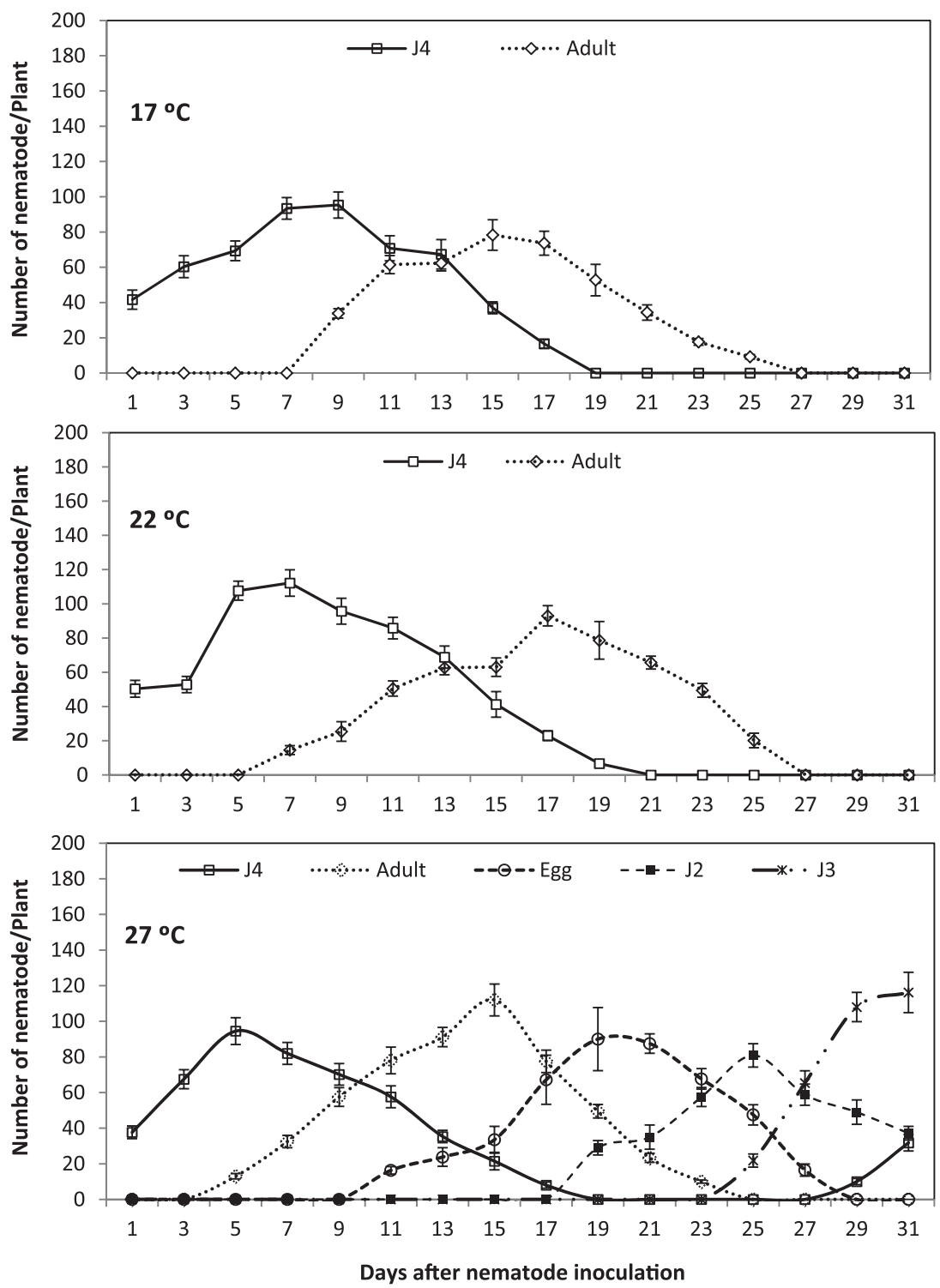

Fig. 1. Mean number of Ditylenchus weischeri recovered by development stage over 31 days in Agassiz yellow pea. J2, J3, and J4 = second-, third-, and fourth-stage juvenile, respectively. Values are mean \pm one standard error $(n=6)$ of the mean of temperature treatments and life stage. 
a much higher temperature was required for reproduction of a plantparasitic nematode on one plant species compared with its preferred host. Perhaps physiological changes in yellow pea itself occurred at $27^{\circ} \mathrm{C}$, allowing for reproduction of $D$. weischeri. The $D$. weischeri minimum generation time was 30 days at $27^{\circ} \mathrm{C}$.

The influence of temperature on nematode reproduction was not surprising because temperature is known to affect plant-parasitic nematode penetration, reproduction, and survival (Griffith et al. 1997; Miyagawa and Lear 1970; Thompson et al. 2015). The results

Table 3. Mean minimum development time (MDT) and accumulated growing degree-days (GDD) of nematode development stages of Ditylenchus weischeri and $D$. dipsaci on yellow pea grown at three temperatures

\begin{tabular}{|c|c|c|c|c|c|c|}
\hline \multirow[b]{3}{*}{ Developmental stage $\mathrm{e}^{\mathrm{z}}$} & \multicolumn{6}{|c|}{ Temperature $\left({ }^{\circ} \mathrm{C}\right)^{\mathrm{y}}$} \\
\hline & \multicolumn{3}{|c|}{$\begin{array}{l}\text { MDT } \\
\text { (days) }\end{array}$} & \multicolumn{3}{|c|}{$\begin{array}{c}\text { GDD } \\
\left({\left.\text { above } 3^{\circ} \mathrm{C}\right)}^{\circ}\right)\end{array}$} \\
\hline & 17 & 22 & 27 & 17 & 22 & 27 \\
\hline \multicolumn{7}{|l|}{ D. weischeri } \\
\hline J4 to adult & $8 \pm 1.5$ & $6 \pm 1.2$ & $5 \pm 1.1$ & 112 & 114 & 120 \\
\hline Adult to egg laying & - & - & $7 \pm 1.2$ & - & - & 168 \\
\hline Egg laying to $\mathrm{J} 2$ & - & - & $8 \pm 1.2$ & - & - & 192 \\
\hline $\mathrm{J} 2$ to $\mathrm{J} 3$ & - & - & $5 \pm 1.1$ & - & - & 120 \\
\hline $\mathrm{J} 3$ to second generation $\mathrm{J} 4$ & - & - & $5 \pm 1.1$ & - & - & 120 \\
\hline Total & $\ldots$ & $\ldots$ & $30 \pm 1.1$ & $\ldots$ & $\ldots$ & 720 \\
\hline \multicolumn{7}{|l|}{ D. dipsaci } \\
\hline $\mathrm{J} 4$ to adult & $6 \pm 1.0$ & $4 \pm 0.5$ & $5 \pm 0.4$ & 84 & 76 & 120 \\
\hline Adult to egg laying & $6 \pm 1.2$ & $4 \pm 1.2$ & $6 \pm 1.2$ & 84 & 76 & 144 \\
\hline Egg laying to J2 & $6 \pm 1.0$ & $4 \pm 1.1$ & $5 \pm 0.3$ & 84 & 76 & 120 \\
\hline $\mathrm{J} 2$ to $\mathrm{J} 3$ & $4 \pm 1.2$ & $3 \pm 1.2$ & $3 \pm 1.1$ & 56 & 57 & 72 \\
\hline $\mathrm{J} 3$ to second generation $\mathrm{J} 4$ & $2 \pm 0.9$ & $3 \pm 0.5$ & $3 \pm 1.1$ & 28 & 57 & 72 \\
\hline Total & $24 \pm 1.2$ & $18 \pm 1.1$ & $22 \pm 1.2$ & 336 & 342 & 528 \\
\hline
\end{tabular}

${ }^{y}$ Each value signifies the mean ( \pm standard error; $n=6$ ); - indicates that development did not proceed to the indicated stage.

${ }^{\mathrm{z}} \mathrm{J} 2, \mathrm{~J} 3$, and $\mathrm{J} 4$ = second-, third-, and fourth-stage juvenile, respectively. of the current study further differentiate the stem nematode species $D$. weischeri and $D$. dipsaci based on temperature requirements to parasitize yellow pea, the former requiring higher mean daily temperatures for development.

When calculating the growing degree-days, knowledge of the base temperature is important (Trudgill 1995; Trudgill et al. 2005). The accumulated growing degree-days is based on physiologically effective temperatures and can be helpful in estimating the occurrence of each developmental stage (Kakaire et al. 2012). In the current study, $D$. weischeri required a minimum of 720 growing degree-days at $27^{\circ} \mathrm{C}$, assuming a base temperature of $3^{\circ} \mathrm{C}$, to complete a life cycle. Base temperatures of 3 to $10^{\circ} \mathrm{C}$ have been reported for several plantparasitic nematode species (Griffith et al. 1997; Mizukubo and Adachi 1997; Ploeg and Maris 1999; Umesh and Ferris 1992). Previously, we observed $D$. weischeri on creeping thistle collected in late summer from fields in Manitoba and Saskatchewan (Tenuta et al. 2014) and reproduction by 90 days on carrot disks at $23^{\circ} \mathrm{C}$ (A. Hajihassani, M. Tenuta, and R. H. Gulden, unpublished). Further, our laboratory routinely rears $D$. weischeri on creeping thistle in growth chambers at 20 to $22^{\circ} \mathrm{C}$, with reproduction evident 1 month after inoculation. However, we have not recovered $D$. weischeri from yellow pea plants in late summer from fields (unpublished) and reproduction at $25^{\circ} \mathrm{C}$ on yellow pea in growth chambers is slight to none (Hajihassani et al. 2016).

Average accumulated growing degree-days, above a $3^{\circ} \mathrm{C}$ base temperature (May to August) for the City of Regina, Saskatchewan, near the geographical center where field pea crops are grown in Canada, is 1,367 (using daily mean temperatures from Environment Canada 2015). This amount is greater than growing degree-days (720) required for $D$. weischeri to complete a generation at $27^{\circ} \mathrm{C}$ on yellow pea obtained in this study. However, D. weischeri has not been recovered from yellow pea fields (Tenuta et al. 2014). If the discrepancy in observations is due to selection of $3^{\circ} \mathrm{C}$ as the base temperature, increasing that value to match the degree-days required to complete a generation observed in our study would be an apparent base temperature of $15^{\circ} \mathrm{C}$. With a base temperature of $15^{\circ} \mathrm{C}$, growing
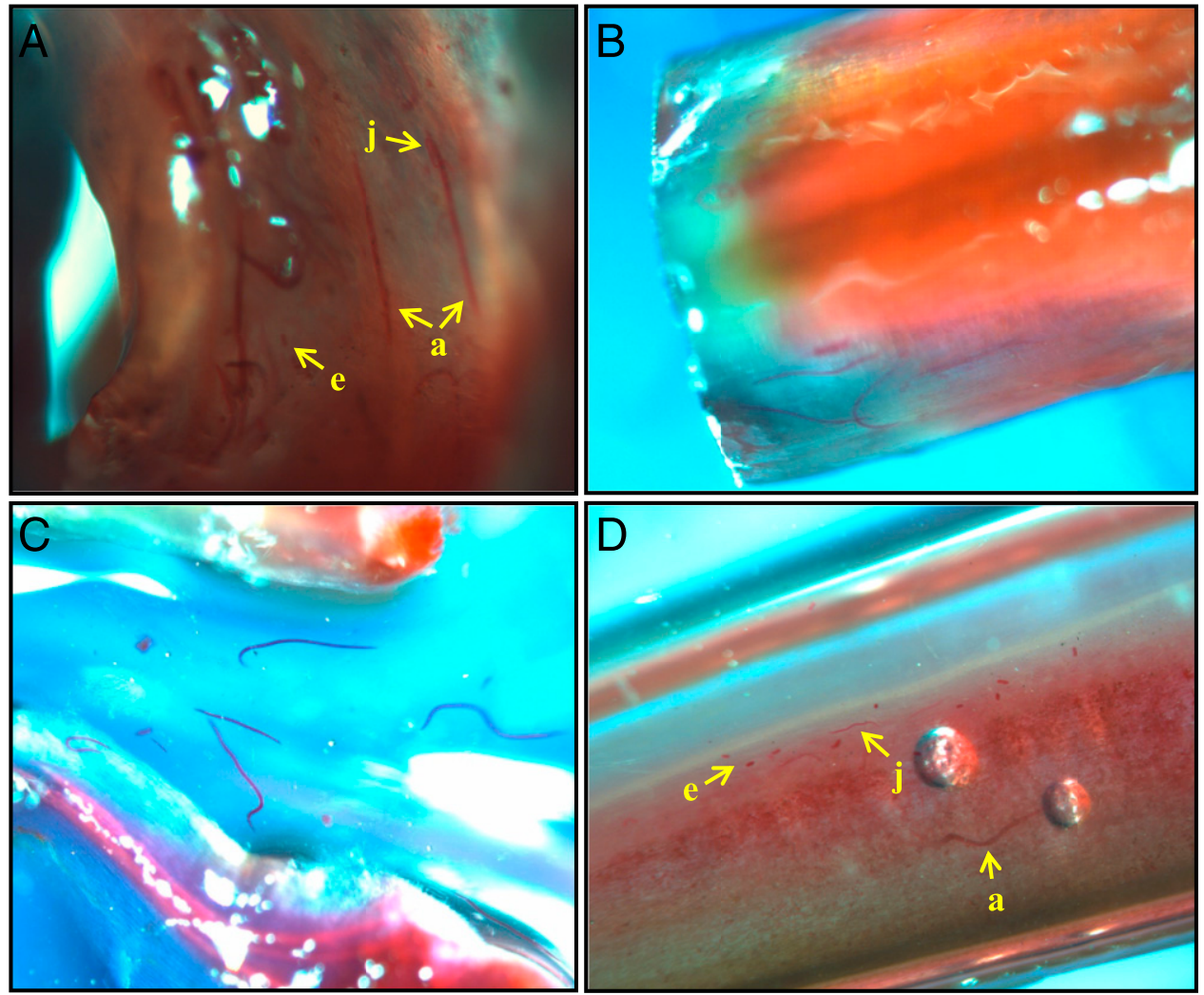

Fig. 2. Magnified ( $\times 20$ magnification) view of Ditylenchus weischeri stained with acid fuchsin in yellow pea grown at $27^{\circ} \mathrm{C}$. Various developmental stages, including eggs (e), juveniles (j), and adults (a), of the nematode in $\mathbf{A}$, base of stem; and B, C, and D, stems. 
degree-days (May through August) for Regina would be 330, which is similar to the 360 obtained using results of this study at $27^{\circ} \mathrm{C}$. However, nematode reproduction on creeping thistle occurs readily in fields and growth chambers at temperatures much lower than $27^{\circ} \mathrm{C}$. Thus, a base temperature of $15^{\circ} \mathrm{C}$ cannot be justified. Rather, the possibility that high temperature may affect yellow pea growth and remove the barrier to $D$. weischeri reproduction warrants further examination

D. weischeri is in pea fields parasitizing creeping thistle in Saskatchewan and Manitoba (Tenuta et al. 2014). It may be that a high sustained mean daily temperature of $27^{\circ} \mathrm{C}$ is required to initiate development of $D$. weischeri on yellow pea. The duration of sustained high temperatures to allow development of the nematode requires further examination. Average daily air temperatures in the pea-growing regions in the Canadian Prairies during the growing season in May, June, July, and August is $12,17,20$, and $19^{\circ} \mathrm{C}$ (for City of Regina, SK, Canada) (Environment Canada 2015) but not $27^{\circ} \mathrm{C}$. Therefore, it seems that mean daily temperatures on the Canadian Prairies are not conducive for $D$. weischeri development on pea crops. Indeed, there are no reports of field damage of yellow pea by $D$. weischeri as well as a lack of presence on yellow pea grain from the Canadian Prairies (Tenuta et al. 2014). The Canadian Prairies have experienced warming over recent decades and it is projected that the mean annual temperature will warm between 1 and $4^{\circ} \mathrm{C}$ from 2020 to 2050 (Blair 2015; Warner 2012). Even if the most pessimistic increase in temperature is achieved, monthly summer mean air temperatures are not expected to reach $27^{\circ} \mathrm{C}$ in this century.

Effect of temperature on $\boldsymbol{D}$. dipsaci development. We observed that temperature affected the penetration of $\mathrm{J} 4$ and subsequent nematode growth and minimum generation time in yellow pea plants. Over the range of temperatures used, penetration of the seedlings by $D$. dipsaci $\mathrm{J} 4$ increased with increasing temperature from 17 to $22^{\circ} \mathrm{C}$ but decreased from 22 to $27^{\circ} \mathrm{C}$. Significantly higher penetration occurred at $22^{\circ} \mathrm{C}$, with $56 \%$ penetration within 5 DAI. Comparable observations have been reported for red clover, where the penetration rate of $D$. dipsaci females increased $2 \mathrm{DAI}$ from $4 \%$ at $4{ }^{\circ} \mathrm{C}$ to $12 \%$ at $20^{\circ} \mathrm{C}$ (Griffith et al. 1997).

In the current study, D. dipsaci completed its generation time 24, 18 , and $22 \mathrm{DAI}$ at 17,22 , and $27^{\circ} \mathrm{C}$, respectively. The development stages of $D$. dipsaci recovered from infested yellow pea at various times corresponded well to the life-cycle observations made by Yuksel (1960) and Tenente and Evans (1998). The generation time
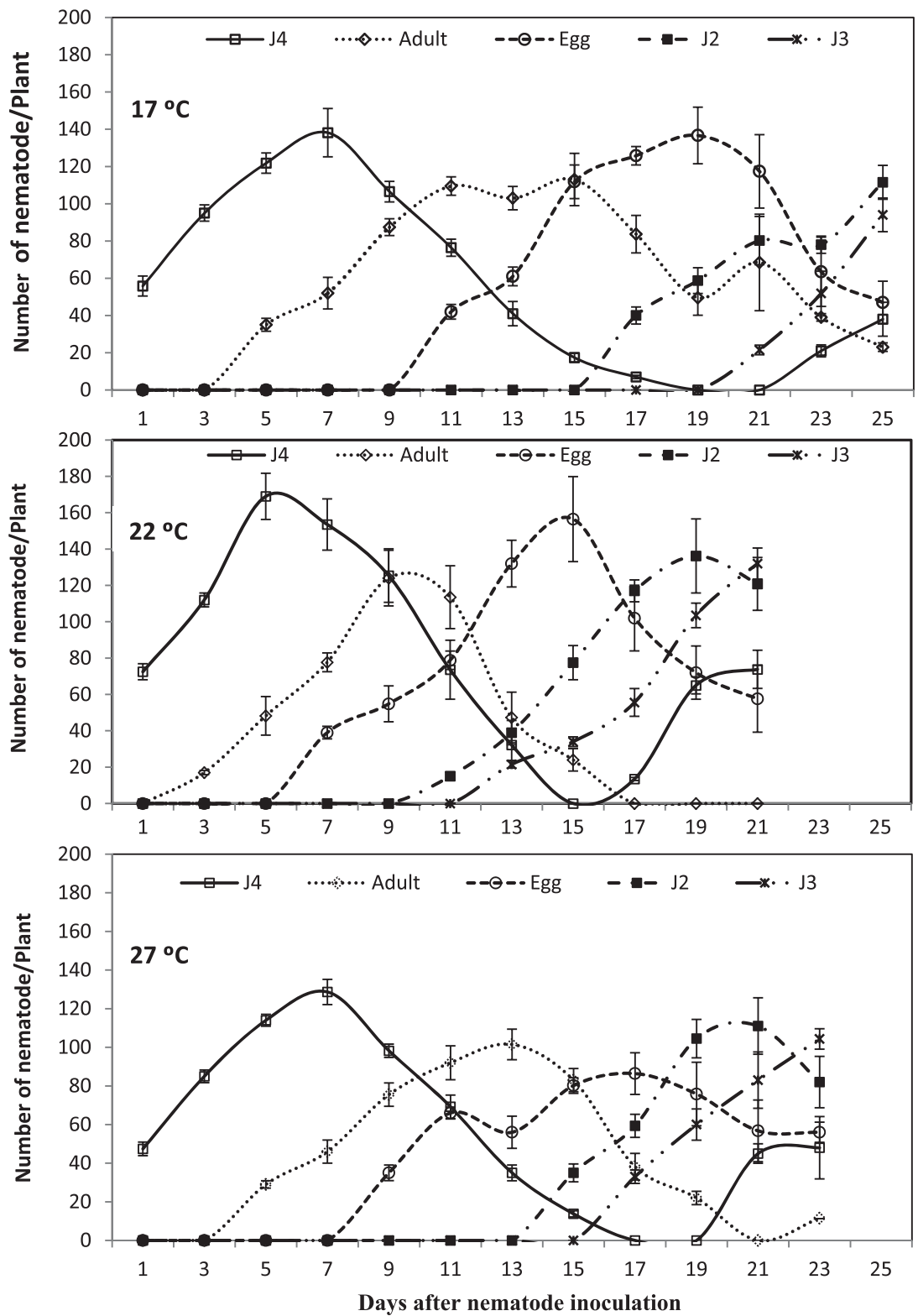

Fig. 3. Mean number of Ditylenchus dipsaci recovered over 25 days in Agassiz yellow pea. J2, J3, and J4 = second-, third-, and fourth-stage juvenile, respectively. Values are the mean \pm one standard error $(n=6)$ of the mean of temperature treatments and life stage. 
of D. dipsaci on onion takes between 19 and 23 days at $15^{\circ} \mathrm{C}$ (Yuksel 1960). The optimum temperature, as defined by Trudgill et al. (2005), is the temperature at which the generation time is shortest. Our results showed that the optimum temperature for $D$. dipsaci development on yellow pea is $22^{\circ} \mathrm{C}$. At this temperature, most $\mathrm{J} 4$ penetration occurred, the egg production began $8 \mathrm{DAI}$, the maximum number of eggs were recovered, and the minimum generation time was 18 days. Results of the present study on temperatures optimal for $D$. dipsaci development and reproduction on yellow pea generally paralleled those found for $D$. dipsaci on onion and alfalfa. Optimum temperature for $D$. dipsaci has been reported to be $20^{\circ} \mathrm{C}$ on alfalfa plants (Griffin 1968) and $21^{\circ} \mathrm{C}$ on onion plants (Sayre and Mountain 1962). In the current study, as temperature increased, the accumulated heat units required to complete the life cycle of $D$. dipsaci increased. This may be related to greater respiration without feeding of the $D$. dipsaci (a temperate crop nematode) at higher temperatures that may result in lower energy available for growth. The accumulated growing units, above a base temperature of $3^{\circ} \mathrm{C}$, were 336 , 342 , and, 528 degree-days at 17,22 , and $27^{\circ} \mathrm{C}$, respectively. These degree-day requirements are comparable with those observed with other D. dipsaci populations. Yuksel (1960) reported that an onion race of $D$. dipsaci required 312 degree-days above a base temperature of $3^{\circ} \mathrm{C}$ to complete one generation at $15^{\circ} \mathrm{C}$.

In conclusion, the current study is the first to report that body length can be used to differentiate juvenile life stages of $D$. weischeri and that rearing on plant host or carrot disk did not affect life-stage differentiation of $D$. weischeri and $D$. dipsaci. The development and minimum generation time of $D$. weischeri on yellow pea differed from that of $D$. dipsaci. D. weischeri completed a minimum generation in 30 days at $27^{\circ} \mathrm{C}$ but not 22 and $17^{\circ} \mathrm{C}$, whereas D. dipsaci's minimum generation time was more optimal at 22 than 17 and $27^{\circ} \mathrm{C}$. Development of $D$. weischeri was arrested to adults with no egg production at temperatures below $27^{\circ} \mathrm{C}$. We hypothesize that the lack of parasitism of $D$. weischeri on yellow pea does not seem to be growing degree-days but, rather, a lack of sustained high mean daily temperature near $27^{\circ} \mathrm{C}$. Even with worst-case scenarios for warming of the Canadian Prairies in the next decades, sustained mean daily temperatures approaching $27^{\circ} \mathrm{C}$ will not be achieved, making development on yellow pea unlikely.

\section{Acknowledgments}

This study was funded by the Alberta Pulse Growers and Manitoba Pulse and Soybean Growers, Saskatchewan Pulse Growers, and Agriculture and Agri-Food Canada Growing Forward II program. We thank M. Celetti for providing garlic bulbs infested with $D$. dipsaci, and also members of the Soil Ecology Laboratory at the University of Manitoba for their technical assistance in this work.

\section{Literature Cited}

Acosta, N., and Malek, R. B. 1979. Influence of temperature on population development of eight species of Pratylenchus on soybean. J. Nematol. 11: 229-232.

Anderson, R. V., and Darling, H. M. 1964. Embryology and reproduction of Ditylenchus destructor Thorne, with emphasis on gonad development. Proc. Helminthol. Soc. Wash. 31:240-256.

Barraclough, R., and Blackith, R. E. 1962. Morphometric relationships in the genus Ditylenchus. Nematologica 8:51-58.

Blair, D. 2015. Prairie Climate Atlas. Online publication. http://www.climateatlas. ca/home.html

Boag, B. 1980. Effects of temperature on rate of feeding of the plant-parasitic nematodes Rotylenchus robustus, Xiphinema diversicaudatum and Hemicycliophora conida. J. Nematol. 12:193-195.

Brown, D. J. F., and Topham, P. B. 1985. Morphometric variability between populations of Xiphinema diversicaudatum (Nematoda: Dorylaimoidea). Rev. Nematol. 8:15-26.

Castillo, P., Trapero-CasaA, J. L., and Jimenez-Diaz, R. M. 1996. The effect of temperature on hatching and penetration of chickpea roots by Pratylenchus thornei. Plant Pathol. 45:310-315.

Chizhov, V. N., Borisov, B. A., and Subbotin, S. A. 2010. A new stem nematode, Ditylenchus weischeri sp. n. (Nematoda: Tylenchida), a parasite of Cirsium arvense (L.) Scop. in the central region of the Non-Chernozem Zone of Russia. Russ. J. Nematol. 18:95-102.

De Waele, D., and Wilken, R. 1990. Effect of temperature on the in vitro reproduction of Ditylenchus destructor isolated from groundnut. Rev. Nematol. 13:171-174.
Doucet, M., Lax, P., Di Rienzo, J. A., Pinochet, J., and Baujard, P. 2001. Temperature-induced morphometrical variability in an isolate of Pratylenchus vulnus Allen \& Jensen, 1951 (Nematoda: Tylenchida). Nematology 3:1-8.

Duncan, L. W., and Moens, M. 2013. Migratory endoparasite nematode. Pages 144-178 in: Plant Nematology, 2nd ed. R. N. Perry and M. Moens, eds. CAB International, Wallingford, UK.

Eisenback, J. D. 2000. Techniques for measuring nematode development and egg production. Pages 16-19 in: Laboratory Techniques in Nematode Ecology. T. Wheeler, T. Forge, and E. Caswell-Chen, eds. Society of Nematologists, Hyattsville, MD.

Environment Canada. 2015. Canadian Climate Normals. Online publication. http://climate.weather.gc.ca/climate_normals/index_e.html

Foot, M. A., and Wood, F. H. 1982. Potato rot nematode, Ditylenchus destructor (Nematoda: Tylenchidae), infecting hops in New Zealand. N. Z. J. Exp. Agric. 10:443-446.

Fortuner, R., and Quénéhervé, P. 1980. Morphometrical variability in Helicotylenchus Steiner, 1952. 2: Influence of the host on H. dihystera (Cobb, 1893) Sher, 1961. Rev. Nematol. 3:291-296.

Griffin, C. D. 1968. The pathogenicity of Ditylenchus dipsaci to alfalfa and the relationship of temperature to plant infection and susceptibility. Phytopathology 58:929-932.

Griffith, G. S., Cook, R., and Mizen, K. A. 1997. Ditylenchus dipsaci infestation of Trifolium repens. 1 . Temperature effects, seedling invasion, and a field survey. J. Nematol. 29:180-189.

Hajihassani, A., Tenuta, M., and Gulden, R. H. 2016. Host preference and seedborne transmission of Ditylenchus weischeri and D. dipsaci on select pulse and non-pulse crops grown in the Canadian Prairies. Plant Dis. 100:1087-1092.

Hooper, D. J. 1972. Ditylenchus dipsaci.Commonwealth Institute of Helminthology Descriptions of Plant Parasitic Nematodes, Set 1, No. 14. CAB International, St. Albans, England.

Jones, B. L., and De Waele, D. 1990. Histopathology of Ditylenchus destructor on peanut. J. Nematol. 22:268-272.

Kakaire, S., Grove, I. G., and Haydock, P. P. J. 2012. Effect of temperature on the life cycle of Heterodera schachtii infecting oilseed rape (Brassica napus L.). Nematology 14:855-867.

Khan, M. R., Handoo, Z. A., Rao, U., Rao, S. B., and Prasad, J. S. 2012 Observations on the foliar nematode, Aphelenchoides besseyi, infecting tuberose and rice in India. J. Nematol. 44:391-398.

Krusberg, L. R. 1961. Studies on the culturing and parasitism of plant-parasitic nematodes, in particular Ditylenchus dipsaci and Aphelenchoides ritzemabosi on alfalfa tissues. Nematologica 6:181-200.

Madani, M., Tenuta, M., Chizhov, V. N., and Subbotin, S. A. 2015. Diagnostics of stem and bulb nematodes Ditylenchus weischeri and D. dipsaci (Nematoda: Anguinidae) using PCR with species specific primers. Can. J. Plant Pathol. 37:212-220.

Miyagawa, S. T., and Lear, B. 1970. Factors influencing survival of Ditylenchus dipsaci (Kuhn, 1857) in Soil. J. Nematol. 2:139-142.

Mizukubo, T., and Adachi, H. 1997. Effect of temperature on Pratylenchus penetrans development. J. Nematol. 29:306-314.

Perry, R. N. 1976. Separation of Ditylenchus dipsaci and D. myceliophagus by body length. Nematologica 22:446-450.

Ploeg, A. T., and Maris, P. C. 1999. Effects of temperature on the duration of the life cycle of a Meloidogyne incognita population. Nematology 1:389-393.

Plowright, R., Caubel, G., and Mizen, K. A. 2002. Ditylenchus species. Pages 107-139 in: Plant Resistance to Parasitic Nematodes. J. L. Starr, R. Cook, and J. Bridge, eds. CAB International, Wallingford, UK.

Saxton, A. M. 1998. A macro for converting mean separation output to letter groupings in Proc Mixed. Pages 1243-1246 in: Proc. 23rd SAS Users Group Int. SAS Institute, Cary, NC.

Sayre, R. M., and Mountain, W. B. 1962. The bulb and stem nematode, Ditylenchus dipsaci, on onion in Southwestern Ontario. Phytopathology 52: 510-516.

Singh, M., and Sharma, S. B. 1994. Temperature effects on development and reproduction of Heterodera cajani on pigeon pea. J. Nematol. 26:241-248.

Sturhan, D., and Brzeski, M. W. 1991. Stem and bulb nematodes, Ditylenchus spp. Pages 423-464 in: Manual of Agricultural Nematology. W. R. Nickle, ed. Marcel Dekker Inc., New York.

Tarte, R., and Mai, W. F. 1976. Morphological variation in Pratylenchus penetrans. J. Nematol. 18:185-195.

Tenente, R., and Evans, A. A. F. 1998. Life cycle of Ditylenchus dipsaci teasel race on onion seedlings under different temperature conditions. Nematol. Bras. 22: $87-96$.

Tenuta, M., Madani, M., Briar, S., Molina, O., Gulden, R. H., and Subbotin, S. A. 2014. Occurrence of Ditylenchus weischeri and not D. dipsaci in field pea harvest samples and Cirsium arvense in the Canadian Prairies. J. Nematol. 46:376-384.

Thompson, J. P., Clewett, T. G., and O'Reilly, M. M. 2015. Temperature response of root-lesion nematode (Pratylenchus thornei) reproduction on wheat cultivars has implications for resistance screening and wheat production. Ann. Appl. Biol. 167:1-10.

Townshend, J. L. 1991. Morphological observations of Pratylenchus penetrans from celery and strawberry in southern Ontario. J. Nematol. 23:205-209.

Trudgill, D. L. 1995. An assessment of the relevance of thermal time relationships to nematology. Fundam. Appl. Nematol. 18:407-417. 
Trudgill, D. L., Honek, A., Li, D., and Van Straalen, N. M. 2005. Thermal timeconcepts and utility. Ann. Appl. Biol. 146:1-14.

Umesh, K. C., and Ferris, H. 1992. Effects of temperature on Pratylenchus neglectus and on its pathogenicity on barley. J. Nematol. 24:501-511.

Vovlas, N., Troccoli, A., Palomares-Rius, J. E., De Luca, F., Liébanasc, G., Landa, B. B., Subbotin, S. A., and Castillo, P. 2011. Ditylenchus gigas n. sp. parasitizing broad bean: A new stem nematode singled out from the Ditylenchus dipsaci species complex using a polyphasic approach with molecular phylogeny. Plant Pathol. 60:762-775.
Warner, M. 2012. Climate change to warm Canada with increased temperatures of up to $2 \mathrm{C}$ by 2020 and $4 \mathrm{C}$ by 2050 . Online publication. https://uwaterloo.ca/ news/news/climate-change-warm-canada-increased-temperatures-2c-2020

Whitehead, A. G., and Hemming, J. R. 1965. A comparison of some quantitative methods of extracting small vermiform nematodes from soil. Ann. Appl. Biol. 55:25-38.

Yuksel, H. S. 1960. Observations on the life cycle of Ditylenchus dipsaci on onion seedlings. Nematologica 5:289-296. 